\title{
Labour Productivity in the New Zealand Construction Industry: A Thorough Investigation
}

Van Tran, (The University of Queensland, Australia)

John Tookey, (Auckland University of Technology, New Zealand)

\begin{abstract}
Productivity growth is strongly correlated to economic growth and increases in welfare. This fact also holds true at the industry level and is particularly true in the NZ construction industry, since productivity growth in this sector may have significant effects on the affordability of housing in the country. In recent years construction in NZ has been subjected to a series of reports that have either highlighted 'failure' to improve productivity or have exhorted the industry to improve its 'poor performance'. However thus far little by way of analysis has gone into the productivity figures that have been quoted, nor has much been done to explain and justify if or why these figures are correct or incorrect. This research seeks to deconstruct construction productivity figures in NZ and explain the patterns over recent years of 'poor performance' in comparison with other industries. I will examine the nature of the NZ construction industry and analyse the historic statistics related to its labour productivity. This will provide an overall understanding of the sector as well as those extraneous factors that may have significant influences on the NZ construction sector. The research found that while factors influencing inputs of labour productivity measure such as labour and material costs remained stable, factors impacting the corresponding outputs such as house and land prices, value of work in Non-residential and Infrastructure construction grew significantly between 1997 and 2007. Given the positive skewing effect of standard economic indicators (inflation etc) on construction labour productivity figures, the relatively poor performance of construction is worrying for the industry. The paper concludes by demonstrating labour productivity in construction is significantly worse performing than previously suspected.
\end{abstract}

Keywords: Construction, Labour productivity, Deconstruction, Industry performance

\section{Introduction}

Productivity addresses the question of how efficiently resources are used in the production of goods and services (Holzer \& Nagel, 1984). It is the key determinant of value, and all other factors that influence value (quality, service, price), of these goods and services. Productivity is one of the important factors that have significant impacts on economic growth, standard of living and increases in welfare (Heap, 1992; Sobhani, 2008; Black et al, 2003). At company level, improving productivity is fundamental to survival of firms because it means that they can meet their obligations to workers, shareholders, and governments while remaining competitive (or even improve competitiveness) in the market. At industry level, productivity improvement is essential for the health of the whole sector, as it is seen as the only valid way to pay for increased standard of living (Heap, 1992). In the context of the construction industry, productivity improvement is particularly important because inadequate increases in productivity will mean shaper rises in construction costs, with adverse social implications and declining work for the industry (Ganesan, 1984). In New Zealand, this holds true because productivity growth in the construction sector may have significant effects on the affordability of housing in the country (Davis, 2007). However, it has been acknowledged that productivity, especially in the construction industry, has always been very difficult to measure and control (Ganesan, 1984; Motwani et al, 1995). Construction tasks are generally complex and inter-dependent such as those in major projects; and are hard to quantify when 
assessing and measuring productivity. This technical difficulty is compounded by the fact that the sector is influenced by external factors such as economic situations (recession or boom periods), political changes (government commitments or effects of legislations) or innovation. Therefore, productivity measures must be treated with care (Heap, 1992).

In recent years, a number of studies have been commissioned to investigate productivity trends, especially labour productivity, in the NZ construction industry. The main reason for this specific consideration is the nature of the industry. Construction is generally a labourintensive industry and improving the productivity of labour constitutes a prime target. Data required for the construction of labour productivity index series are more readily available than other series. Capital productivity series are hard to obtain. Statistics New Zealand (SNZ) publishes labour data quarterly, whereas the capital series for construction is given yearly.

Although these studies vary significantly in details and depth, they nonetheless highlight some worrying signs for the sector. Growth of labour productivity in NZ construction has been low and productivity level has declined over time. In order to address this issue formally, a Productivity Taskforce made up of industry and central government leaders was established in 2009 to overlook and develop:

- a sector wide skills strategy

- an improved approach to the procurement of construction projects

This research project was initiated from the lack of understanding of data presented in Fig. 1. The objective of the research is to deconstruct "broad brush" statistics into a more meaningful representation of labour productivity in the NZ construction industry. Without clear delineation between industry section and representation of external impact factors, NZ construction's "productiveness" cannot be fully understood and therefore may impede the effort to improve the performance of the industry. This research serves as the foundation for further investigations into this subject matter in New Zealand.

Labour productivity in the aggregate economy and the construction sector compared $(1997-2008)$

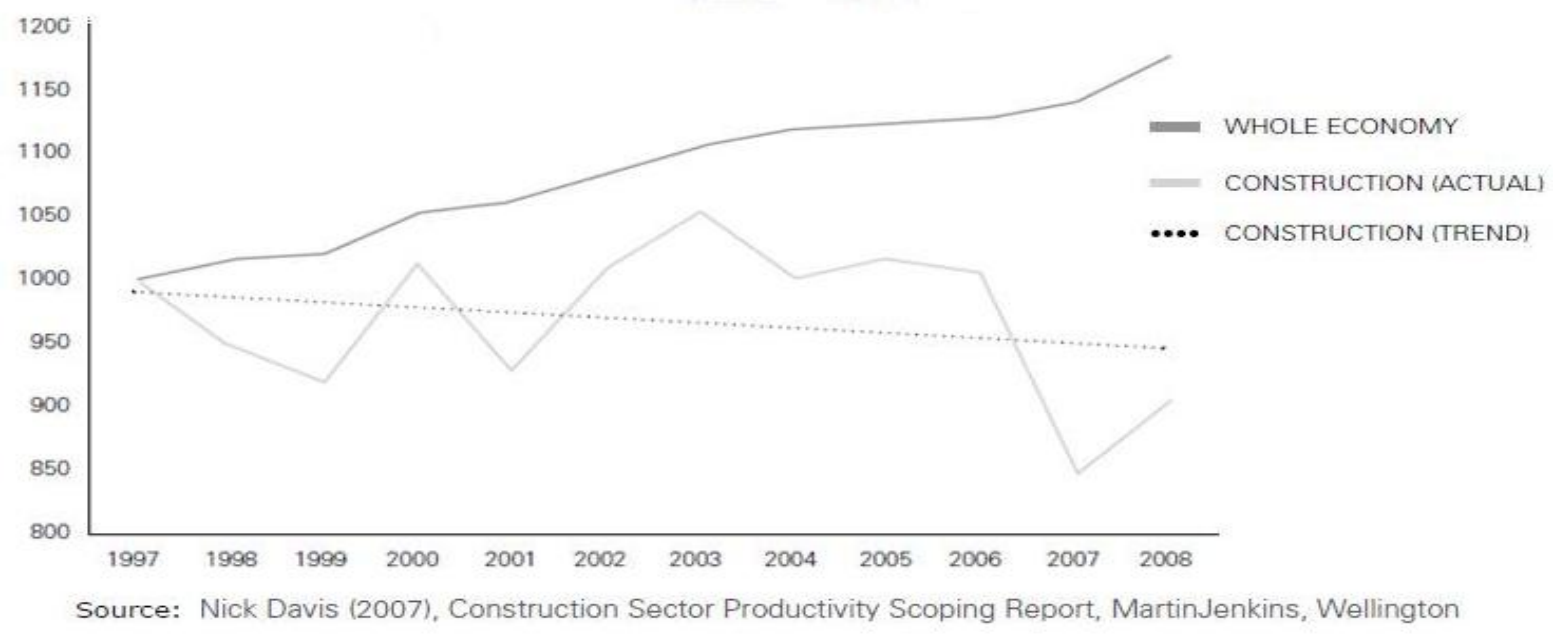

Figure 1 Labour Productivity Figure

\section{Research Aims and Objectives}

Productivity studies into NZ construction have either highlighted 'failure' to increase productivity or have exhorted the industry to 'improve' its 'poor performance' (Black et al, 2003; Davis, 2007; Janssen et al, 2008; Taskforce, 2009). Little by way of analysis has gone into the productivity figures quoted, nor has much been done to explain and justify if or

Tran, V and Tookey, J (2011) 'Labour productivity in the New Zealand construction industry: A thorough investigation', Australasian Journal of Construction Economics and Building, 11 (1) 41-60 
why these figures are correct or incorrect. Further, the problem with productivity measurement is a significant issue in NZ. Currently no official measure of labour productivity exists (Davis, 2007). A problem compounded by other extant problems such as the availability and quality of data. Previous productivity studies conflate statistics. This is to reduce the complexity of their explanations in order to motivate construction to redouble its efforts to innovate and improve performance. This is a conceptually difficult position to sustain. There would appear to be a tendency for reports citing such limited statistical evidence as those in Figure 1 to seek to push an agenda onto the construction industry, and indicate a willingness to selectively cite statistics outside of context.

The research reported here sought to investigate these issues and thus "unpack" the complex problem of labour productivity in construction. Extraneous factors which may have significant influences on labour productivity, but have been largely ignored or overlooked in previous studies, such as land/house prices; inflation and associated costs (labour, material) are incorporated in order to establish a more complete context intended to be useful for further investigation into the performance of labour productivity in NZ.

The formulated objectives for the research are stated as follows:

i) To re-examine existing studies on labour productivity in NZ construction;

ii) To identify factors which have significant effects on construction labour productivity;

iii) To set up a platform for future research in this area in NZ

\section{Defining Productivity}

Productivity was formally defined by the Organisation for European Economic Cooperation as: "the quotient obtained by dividing output by one of the factors of production. In this way it is possible to speak of productivity of capital, investment, or raw materials according to whether output is being considered in relation to capital, investment or raw materials, etc". It must be noted that productivity is a relative concept with comparisons either being made across time or between different production units.

Productivity is represented by:

$$
\frac{\text { Output obtained }}{\text { Input expended }}
$$

where unit of measurement of both outputs and inputs is given in dollar values (NZD\$) or in any other relevant unit.

\section{Index Number Methodology}

A productivity index is defined as the ratio of an output index to an input index, that is:

$$
A^{t}=\frac{Q^{t}}{I^{t}} ; t=0 \ldots T
$$

where $A^{t}$ is a labour productivity index, $Q^{t}$ is an output index and $I^{t}$ is a labour input index. Each index represents accumulated growth from period 0 to period $t$.

Some of the most common index formulae (Laspeyres, Paasche, Fisher and Tornqvist) are included here. Suppose information on prices and quantity of I outputs is available for period $\mathrm{t}=0 \ldots \mathrm{T}$. Denote the price and quantity vectors as $p^{t}=\left(p_{1}{ }^{t}, \ldots, p_{I}{ }^{t}\right)$ and $q^{t}=\left(q_{1}{ }^{t}, \ldots, q_{I}{ }^{t}\right)$ respectively; the Laspeyres $\left(L^{t}\right)$, Paasche $\left(P^{t}\right)$, Fisher $\left(F^{t}\right)$, Tornqvist $\left(T^{t}\right)$ quantity indices are defined as follows:

$$
L^{t}=\frac{\sum_{i} p_{i}^{0} \times q_{i}{ }^{t}}{\sum_{i} p_{i}^{0} \times q_{i}^{0}}
$$

Tran, V and Tookey, J (2011) 'Labour productivity in the New Zealand construction industry: A thorough investigation', Australasian Journal of Construction Economics and Building, 11 (1) 41-60 


$$
\begin{gathered}
P^{t}=\frac{\sum_{i} p_{i}{ }^{t} \times q_{i}{ }^{t}}{\sum_{i} p_{i}{ }^{t} \times q_{i}{ }^{0}} \\
F^{t}=\left(L^{t} \times P^{t}\right)^{\frac{1}{2}} \\
T^{t}=\prod_{i}\left(\frac{q_{i}{ }^{t}}{q_{i}^{0}}\right)^{\frac{1}{2} \times\left(w_{i}{ }^{0}+w_{i} t\right)} \\
\text { for } t=0, \ldots, T \text { and } i=1, \ldots, I \text { and where } \\
w_{i}{ }^{t}=\frac{p_{i}{ }^{t} \times q_{i}{ }^{t}}{\sum_{i} p_{i}{ }^{t} \times q_{i}{ }^{t}}
\end{gathered}
$$

Of these, Tornqvist and Fisher index formulae are the most widely used by statistics officials around the world.

\section{Partial Productivity}

Partial productivity is the ratio of output to one class of input (labour, capital or material). In this paper, emphasis is on labour productivity because, as Janssen et al (2008) noted:

- It is closely related to individual incomes and therefore living standard

- It can be measured with reasonable reliability

Labour productivity measures can be based on either a gross output or on the value-added concept. The simplest measure of labour productivity is output per worker. An increase in output per worker can be observed either by requiring workers to produce more in the hours they work or if they work longer hours. The latter is a disadvantage of this definition.

The second measure of labour productivity is output per hour worked. The advantage of this method is that it takes into account variations of number of hours worked per worker, rather than the numbers of employees, as the measure of labour input. With an increase in parttime employment, hours worked provides the more accurate measure of labour input. But the main disadvantage is that the hours worked data is less reliable than the employment data.

\section{Multifactor Productivity}

Multifactor productivity (MFP) is the ratio of the value-added concept of output to the sum of associated labour and capital inputs. MFP indices show the time profile of how productively combined labour and capital inputs are used to generate added value. This method serves as an analysis of micro-macro links, such as the contribution of an industry to the economywide multifactor productivity growth and living standards (OECD, 2002). The main advantage of MFP measure is the ease of aggregation across industries and that the data required is directly available from national accounts. However, its main drawbacks and limitations are that the multifactor productivity is not a good measure of technology shifts at the industry level. When based on value added that has been double-deflated with a fixed weight Laspeyres quantity index, the measure suffers from the conceptual and empirical drawbacks of this concept (OECD, 2002). In this research, the focus is on partial productivity types of measurements and is based on the value-added concept.

\section{Methodology}

Interviews with practitioners such as developers, consultants and contractors in New Zealand were carried out in order to obtain experience and attitudes to the variety of factors involved in productivity. Questions were prepared with the objectives of obtaining information relating to procurement choice and satisfaction with procurement methods used by organisations. The interviews were carried out with willing practitioners using a five point

Tran, V and Tookey, J (2011) 'Labour productivity in the New Zealand construction industry: A thorough investigation', Australasian Journal of Construction Economics and Building, 11 (1) 41-60 
scale for data analysis. Data collected was analysed using statistical methods to extract meaningful information to aid the understanding of the graph presented in the Davis report as well as to provide a valuable resource to build a foundation for future practice in New Zealand.

\section{Literature Review}

As stated, a number of studies have attempted to address the issue of labour productivity in the NZ construction industry. Here, their findings are summarised to provide readers an overview of the subject matter being discussed in this research. In their working paper for the New Zealand Treasury, Black et al (2003) established a productivity series for the New Zealand economy for the period 1988 to 2002. Results of this study show that on average, the multifactor productivity growth in the construction industry was the worst in all sectors considered. From 1988 to 2002, the MFP of the construction industry declined by an average of $1.5 \%$ per annum while the average growth of MFP of the whole economy is $0.88 \%$ per annum. Figure 2 illustrates the effect of poor MFP growth in the sector over time. By 2002, performance of MFP in the construction sector was almost $20 \%$ lower than that in 1988. This is a significant decline.

\begin{tabular}{|c|c|c|c|c|c|}
\hline March Year & Primary & $\begin{array}{c}\text { Mining \& } \\
\text { Quarrying }\end{array}$ & Construction & Manufacturing & $\begin{array}{c}\text { Electricity, } \\
\text { Gas \& Water }\end{array}$ \\
\hline $\mathbf{1 9 8 8}$ to $\mathbf{1 9 9 3}$ & $-0.52 \%$ & $-1.91 \%$ & $-4.59 \%$ & $0.29 \%$ & $1.11 \%$ \\
\hline $\mathbf{1 9 9 3}$ to $\mathbf{2 0 0 2}$ & $2.45 \%$ & $0.72 \%$ & $0.25 \%$ & $-0.16 \%$ & $-0.93 \%$ \\
\hline $\mathbf{1 9 8 8}$ to $\mathbf{2 0 0 2}$ & $1.38 \%$ & $-0.23 \%$ & $-1.51 \%$ & $0.00 \%$ & $-0.21 \%$ \\
\hline
\end{tabular}

\begin{tabular}{|c|c|c|c|c|}
\hline March Year & $\begin{array}{c}\text { Transport \& } \\
\text { Communications }\end{array}$ & $\begin{array}{c}\text { Business \& } \\
\text { Property } \\
\text { Services }\end{array}$ & $\begin{array}{c}\text { Personal \& } \\
\text { Community } \\
\text { Services }\end{array}$ & $\begin{array}{c}\text { Retail \& Wholesale } \\
\text { trade }\end{array}$ \\
\hline $\mathbf{1 9 8 8}$ to $\mathbf{1 9 9 3}$ & $6.75 \%$ & $-2.54 \%$ & $0.82 \%$ & $-0.38 \%$ \\
\hline $\mathbf{1 9 9 3}$ to $\mathbf{2 0 0 2}$ & $5.52 \%$ & $0.74 \%$ & $1.48 \%$ & $1.40 \%$ \\
\hline $\mathbf{1 9 8 8}$ to $\mathbf{2 0 0 2}$ & $5.95 \%$ & $-0.44 \%$ & $1.24 \%$ & $0.75 \%$ \\
\hline
\end{tabular}

Table 1 Average Multifactor Productivity Growth by Industry

Source: BGM (2003)

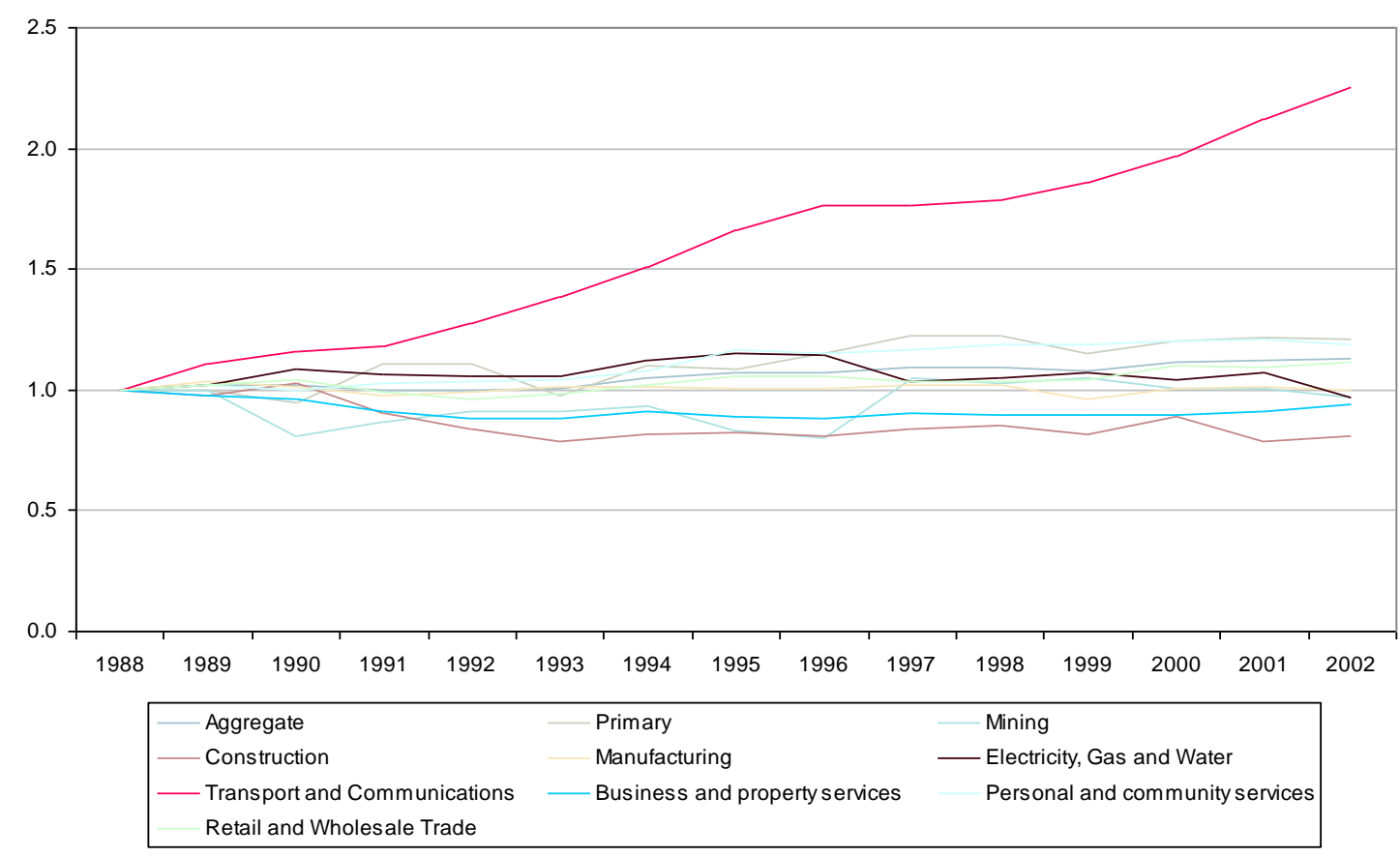

Tran, V and Tookey, J (2011) 'Labour productivity in the New Zealand construction industry: A thorough investigation', Australasian Journal of Construction Economics and Building, 11 (1) 41-60 
Davis (2007) report was prepared on behalf of the Department of Building and Housing. It found that there is a problem with the performance of the construction industry productivity, namely:

- All three productivity measures in the construction sector is much lower than those in the aggregate market sector

- Over this period, labour productivity in the construction industry has fallen short of aggregate labour productivity growth by 10 percentage point

\begin{tabular}{|l|c|c|c|c|c|c|}
\hline & \multicolumn{3}{|c|}{ Construction Sector } & \multicolumn{3}{c|}{ Aggregate Economy } \\
\hline & Labour & Capital & Multifactor & Labour & Capital & Multifactor \\
\hline $\begin{array}{l}\text { Average annual } \\
\text { growth rate }\end{array}$ & $0.3 \%$ & $-0.2 \%$ & $0.3 \%$ & $1.3 \%$ & $0.2 \%$ & $0.9 \%$ \\
\hline $\begin{array}{l}\text { Standard } \\
\text { deviation }\end{array}$ & $6.4 \%$ & $7.9 \%$ & $6.4 \%$ & $1.1 \%$ & $1.4 \%$ & $1.2 \%$ \\
\hline
\end{tabular}

Table 2 Comparative Productivity Statistics (1997-2006) Source: Department of Building and Housing

Janssen \& McLoughlin (2008) is part of a series of working papers that the New Zealand Treasury aims at addressing NZ's long term productivity performance and factors that may be inhibiting NZ from reaching its potential; and it "examines the evidence surrounding New Zealand's productivity performance at an aggregate level" (Janssen et al, 2008). Table 3 shows that while of labour productivity in the 13 measured sectors considered experience an increase of $0.3 \%$ per annum, the construction industry exhibits the lowest level of growth in labour productivity, with a decrease of $3.1 \%$ per annum despite its high employment growth. The expansion of employment was mainly due to factors such as high net migration inflow, previously low interest rates, declining household sizes and infrastructure investment (Janssen, 2008). It was postulated that the possible cause for the lower-than-expected observed labour productivity growth in recent years was due to changes occurring in the NZ labour work force: "during times of high employment growth, new workers tend to dampen observed productivity growth". This is apparently because as new workers enter employment and even if they have high levels of formal qualifications, they are generally less productive than existing workers. As a consequence, the observed productivity experiences a temporary reduction, until these workers gain sufficient job-relevant knowledge or experience, when productivity should return to its original rate.

In 2008, the New Zealand Centre for Advanced Engineering (CAENZ) carried out a study into the cyclical nature of the New Zealand construction industry. The aim of this study was to "establish and communicate a shared understanding of the key drivers in the boom/bust cycles of the construction industry in NZ" (Allan et al, 2008). Overall, much of the construction industry boom bust effect in New Zealand is caused by the industry's own internal system structure and behaviour rather than external shocks. A new thinking must be adopted by the industry and policy makers which:

- Recognises how co-dependencies and industry dynamics drive behaviours and profitability

- Adopt structures and cultures that reinforce communication and information sharing throughout the industry, particularly across industry sectors

- Encourages long-term strategic thinking instead of short-term profit seeking and speculation (Allan et al, 2008)

Tran, V and Tookey, J (2011) 'Labour productivity in the New Zealand construction industry: A thorough investigation', Australasian Journal of Construction Economics and Building, 11 (1) 41-60 


\begin{tabular}{l|c|c|c|c}
\hline \multirow{2}{*}{$\begin{array}{l}\text { Annual average growth (\%) } \\
\text { Total measured sector }\end{array}$} & Output & Jobs & \multicolumn{2}{c}{$\begin{array}{c}\text { Labour productivity } \\
\text { (output per job) }\end{array}$} \\
\hline Primary & & & $\begin{array}{c}\text { Contribution } \\
\text { (percentage } \\
\text { points) }\end{array}$ \\
\hline Manufacturing & 3.4 & 3.1 & 0.3 & 0.3 \\
\hline Electricity, gas \& water & 1.5 & 2.7 & -1.2 & -0.1 \\
\hline Construction & 1.9 & 0.9 & 1.0 & 0.2 \\
\hline Wholesale trade & 1.4 & -0.9 & 2.2 & 0.0 \\
\hline Retail trade & 4.1 & 7.4 & -3.1 & -0.2 \\
\hline Hospitality & 2.4 & 2.6 & -0.2 & 0.0 \\
\hline Transport \& storage & 4.6 & 3.1 & 1.5 & 0.1 \\
\hline Communications & 3.0 & 3.5 & -0.6 & 0.0 \\
\hline Finance \& insurance & 3.0 & 2.9 & 0.1 & 0.0 \\
\hline Business services & 6.8 & 0.3 & 6.5 & 0.3 \\
\hline Culture \& recreation & 4.9 & 2.8 & 2.1 & 0.2 \\
\hline Personal \& other & 5.0 & 4.3 & 0.6 & 0.0 \\
\hline
\end{tabular}

Source: Gross Domestic Product, Linked Employer-Employee Data (December 2006 year was used for job growth as data for the March 2007 quarter were not avallable), Statistics New Zealand; Treasury calculations

Table 3 Output, Jobs, Labour Productivity and Contribution to Labour Productivity Growth by Industry (seven years to March 2007)

On the other hand, the construction industry has provided a significant amount of support to the NZ labour market, with number of individuals employed by this industry accounting for nearly $10 \%$ of the NZ workforce. However, construction employment has suffered from a cyclical pattern of skills shortages in times of peak demand, and surplus workers when demand is low. Department of Labour found that construction employment tends to expand rapidly during the boom periods ( $23 \%$ on average), with the appearance of many individuals in many construction trades. But, this expansion tends to dampen growth of labour productivity because these individuals often need time to be productive in their work. The labour force also tends to shrink fast during recessionary times like the one currently experienced, principally within the trade workers occupational group. Employment of professionals in construction, such as architects and engineers, and employment of labourers often hold up well. The DOL (2009) report also notes that any loss of skilled workers and trainees would likely to impair the productivity of the industry when demand picks up again.

\section{Areas of Investigation}

The NZ construction industry comprises a number of sub-industries which can be considered independently. These sub-industries are: Civil construction, Building Services, Residential and Non-Residential and Infrastructure Construction. In this research, the emphasis is on the last three categories. The rationale behind this lies in the fact that civil construction is a machine dominated sub-industry and as such, workers in civil construction are more "productive" in value-added terms than those in the rest in the construction industry (Page, 2010). Therefore, it is important that we investigate the lower end of this industry. With this in mind, extraneous factors which had not been included in previous studies such as land and house prices, infrastructure investments in NZ etc, were explored in detail in this section. 


\section{Inflation}

Inflation has a significant effect on labour productivity. As the cost of labour increases, productivity goes down. As the selling price of the built product increases relative to labour cost, labour productivity goes up. The inflation series in NZ are available on SNZ website. These series date as far back as the first quarter of 1920.

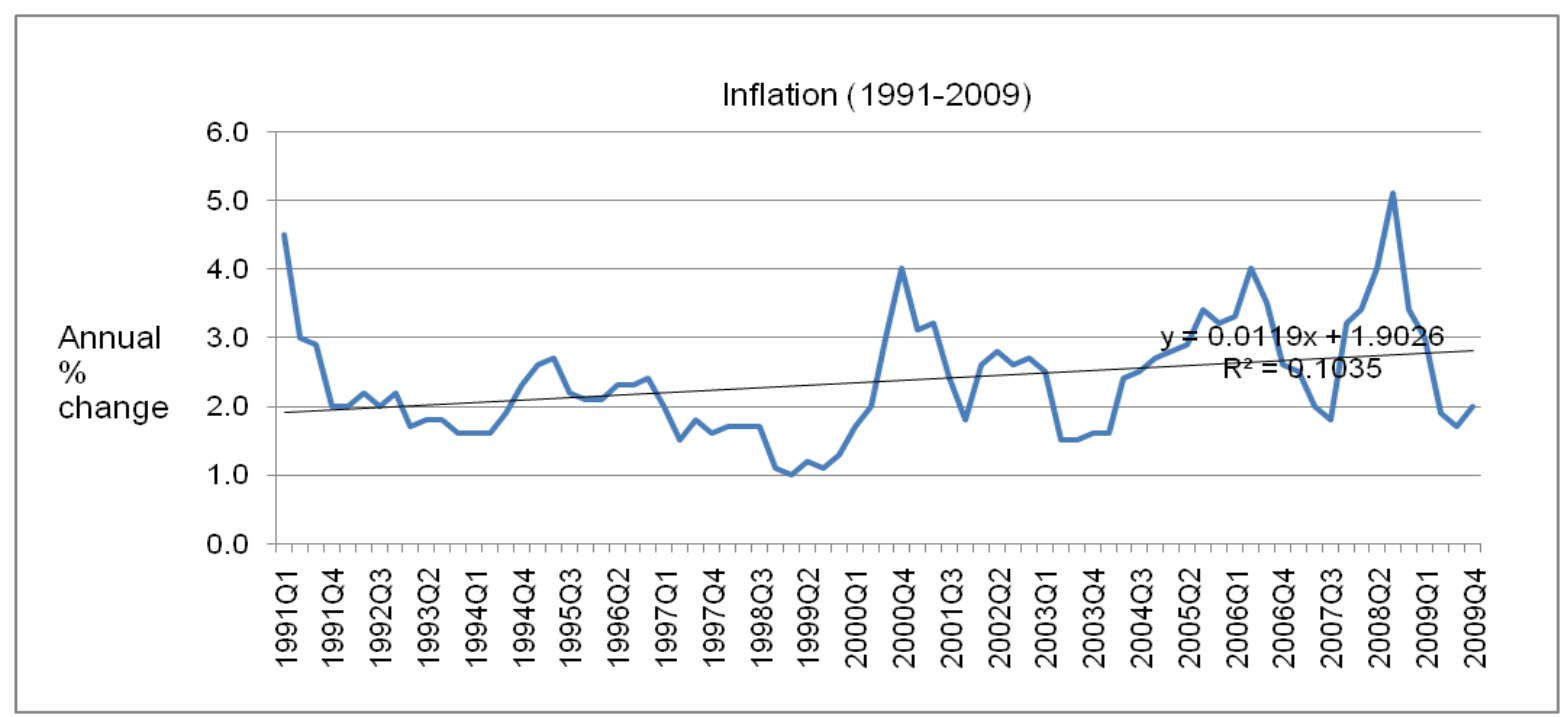

Figure 3 NZ Inflation 1991-2009

Source: SNZ, RBNZ. Note: Interest rates are excluded

Since the introduction of the Goods and Services Tax (GST) in October 1986 and the subsequent GST changes in June 1989, NZ inflation in a number of quarters were impacted, specifically, quarter 4 of 1986 to quarter 1 of 1988 and quarter 3 of 1989 to quarter 4 of 1990 respectively. However, since 1991, the impact of GST on inflation in NZ is almost nonexistent (Fig. 2). As can be seen here, the linear regression line is almost flat. An estimate of inflation growth averaging $3 \%$ p.a. is reasonable for the time period. But there seems to be a degree of volatility in inflation. And this volatility may have certain implications on the performance of labour productivity in NZ construction.

\section{Employment}

Employment in NZ construction is apparently quite volatile. Despite a strong growth of employment in construction between 2001 and 2007 (63\% in comparison to the 18.8\% employment growth in NZ over the same period), year to year growth rates in construction showed a greater degree of variation. After a period of sustained growth (2001-2004), NZ construction experienced a slow-down in employment growth, even though the number of employed individuals in the sector was still increasing. Employment in construction peaked in 2007 with the number of filled jobs in the industry growing to 123,580 . However, by December 2008, the industry had lost some 3000 jobs. Table 13 shows the numbers of wage and salary earners identified by being directly involved in various trades in the NZ construction sector. The overall employment growth in all sub-industries considered here was quite substantial (54.6\%). The greatest change in employment between 2001 and 2006 happened in the "Other Construction Services" category (90.8\%). On the other hand, the "Building Completion Services" category had the lowest growth rate among these subindustries (41.4\%). However, employment growth in this sub-industry was still 2.5 times higher than that of the whole economy period (16.4\%). 


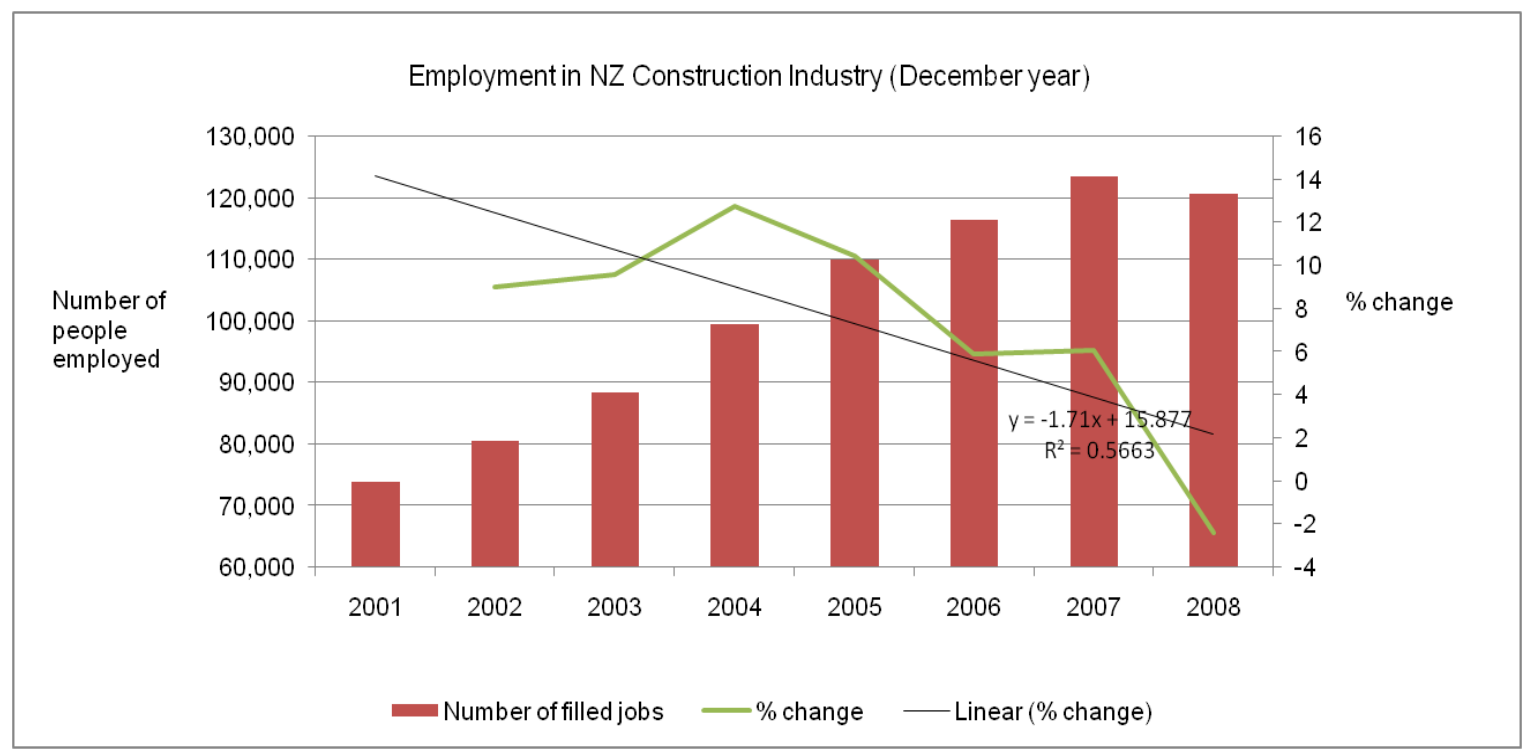

Figure 4 Employment in NZ Construction Industry (2001-2008)

Source: SNZ

\section{Wage and Salary Earners in Construction Industry March years}

\begin{tabular}{|c|c|c|c|c|c|c|c|c|}
\hline \multirow[b]{2}{*}{ Sub-industry } & 2001 & 2002 & 2003 & 2004 & 2005 & 2006 & \multicolumn{2}{|c|}{$\begin{array}{c}\text { Change between } 2001 \\
\text { and } 2006\end{array}$} \\
\hline & \multicolumn{6}{|c|}{ Number of people } & Absolute & $\%$ \\
\hline Building construction & 15,672 & 16,056 & 18,117 & 21,003 & 24,666 & 27,102 & 11,430 & 72.9 \\
\hline Non-building construction & 17,547 & 17,928 & 18,189 & 19,170 & 22,164 & 24,717 & 7,170 & 40.9 \\
\hline Site preparation services & 4,854 & 5,112 & 5,622 & 6,225 & 7,470 & 8,103 & 3,249 & 66.9 \\
\hline Building structure services & 4,191 & 4,305 & 4,956 & 5,769 & 6,543 & 7,107 & 2,916 & 69.6 \\
\hline Installation trade services & 16,605 & 17,322 & 18,468 & 20,148 & 21,396 & 23,718 & 7,113 & 42.8 \\
\hline Building completion services & 10,272 & 10,251 & 11,247 & 12,459 & 13,917 & 14,529 & 4,257 & 41.4 \\
\hline Other construction services & 4,512 & 4,455 & 5,460 & 6,126 & 7,221 & 8,610 & 4,098 & 90.8 \\
\hline Total & 73,656 & 75,426 & 82,062 & 90,903 & 103,374 & 113,889 & 40,233 & 54.6 \\
\hline
\end{tabular}

Table 4 Wage and Salary Earners in Construction Industry

Source: SNZ

It is apparent that the sustained growth in employment in construction 1997-2007 was accompanied by an almost continuous decline in labour productivity. The causes of this apparent strong correlation are moot. However, a number of potential candidates for this decline have been posited education, training, declining skills, declining popularity of apprentice schemes etc (Taskforce, 2009). One has to be careful in interpreting the results presented because certain sub-industries are actually more "productive" in terms of labour than others. For instance the civil construction sector has traditionally been a machinerydominated industry and the personnel employed in that sector are few but most (if not all) are highly specialised. As the result, this sector has always had significantly higher output per man hour compared with other sub-industries in NZ construction, which in turns means that labour productivity in this sub-industry is much higher than that of the overall industry. In spite of the skewing effects of civil construction, and the expanded amount of civil infrastructure works of recent years, construction labour productivity is still declining. This is extremely concerning for the NZ construction sector. 


\section{Labour Costs}

The labour cost series in this research was provided by BRANZ (Page, 2010). Labour cost index in the construction industry was compared with labour cost indices in other sectors (manufacturing; electricity, gas and water supply) and with those in all industries. Overall, labour costs in construction behave much like those in the wider economy and in general performed better than those in some other major industries (Electricity, Gas and Water Supply for instance). In terms of earnings in NZ, the average for a working person in the country did improve significantly in the 21-year period (from $\$ 12.2 / \mathrm{hr}$ in 1988 to $\$ 25.4 / \mathrm{hr}$ in 2009), but the rate at which this improvement takes place is sluggish, averaging $3 \%$ over the period. In effect, wage growth tracked inflation almost exactly. Growth rates in NZ construction in general follow the same patterns as those in the aggregate economy (Fig. 9). From 1997 to 2007, both series show strong growth (3.7\% p.a.), with actual wages increased from $\$ 16.4 / \mathrm{hr}$ to $\$ 23.2$ respectively. This strong performance might have been due to the favourable economic conditions in NZ in this period, in which the construction boom from 2001-2004 might have played a significant part. It is interesting to note that despite the strong growth, the labour costs in both the NZ construction and the wider economy in effect grew at almost the same rate as inflation over the periods considered. This means the real labour costs in the construction industry have actually remained flat. This finding is significant to the analysis presented in this paper.

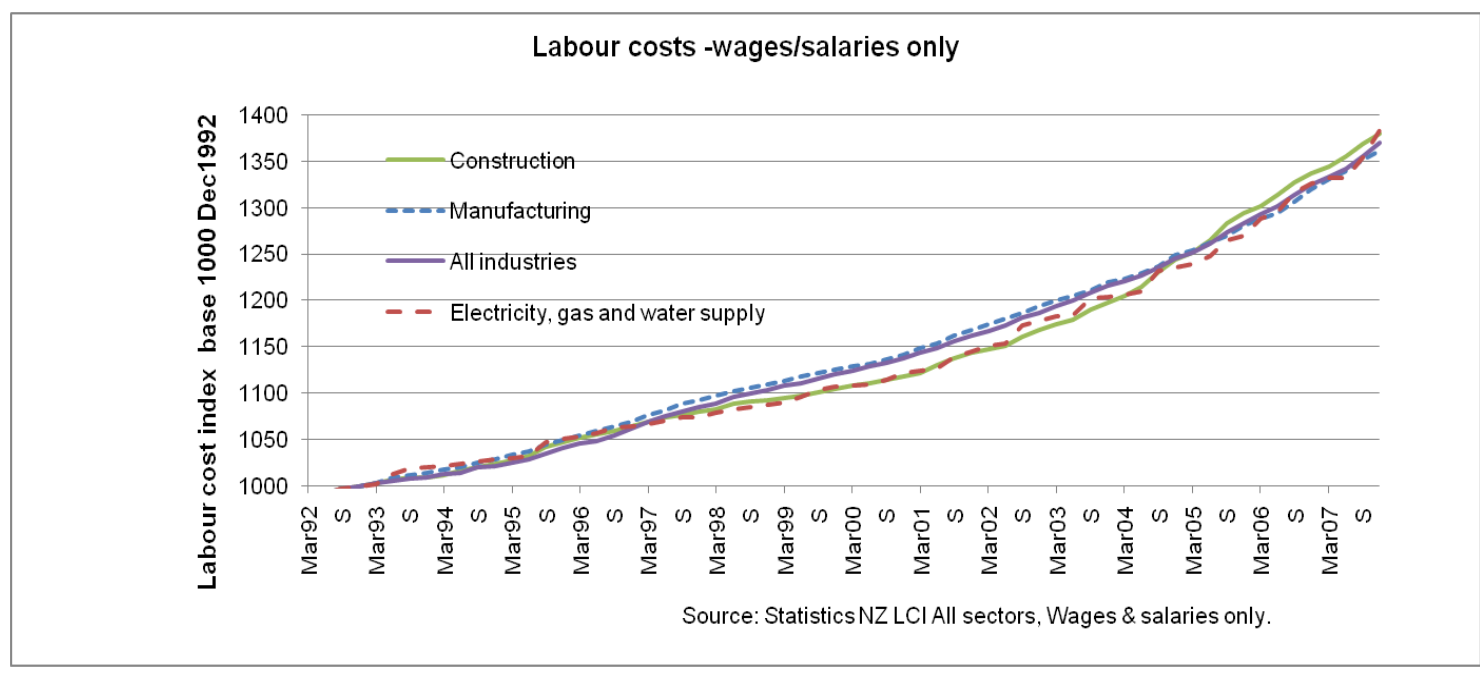

Figure 5 Labour Costs-Wages/Salaries only

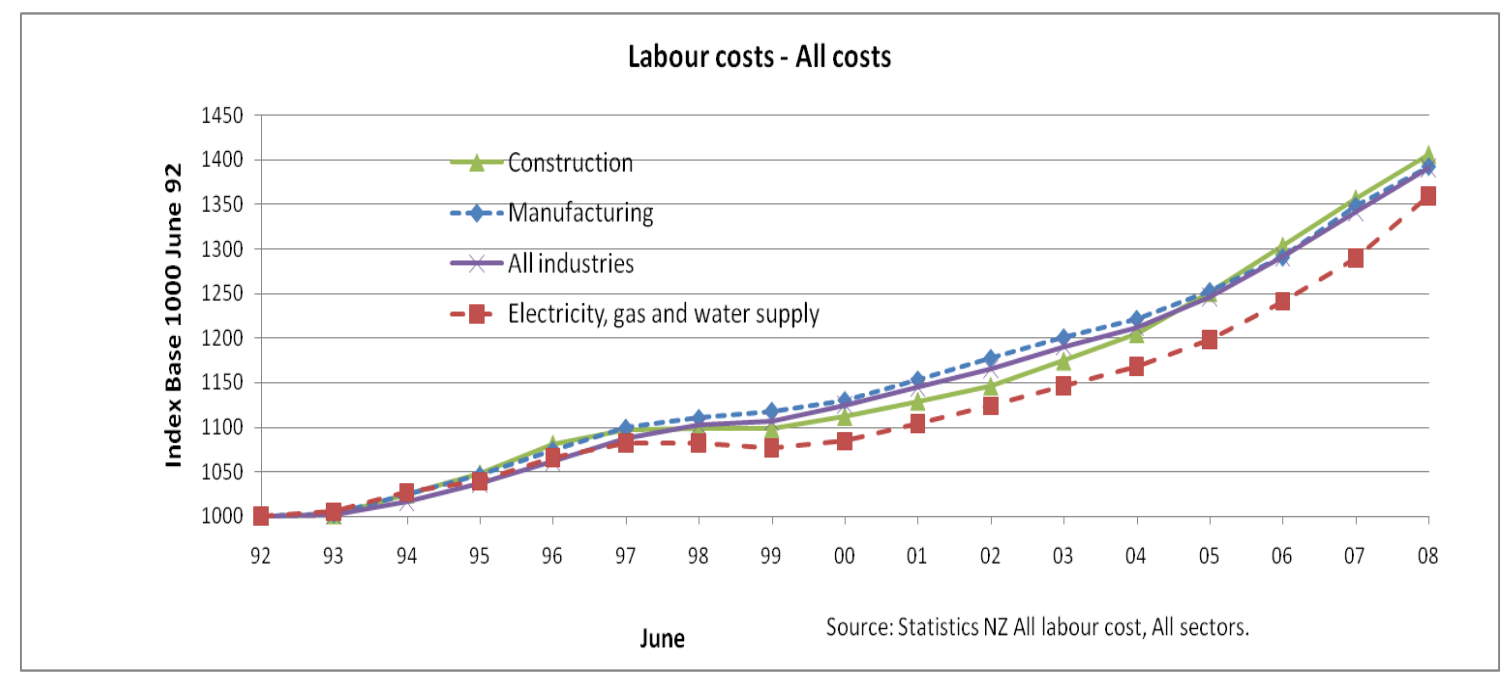

Figure 6 Labour Costs-All Costs

Source: SNZ, BRANZ

Tran, V and Tookey, J (2011) 'Labour productivity in the New Zealand construction industry: A thorough investigation', Australasian Journal of Construction Economics and Building, 11 (1) 41-60 


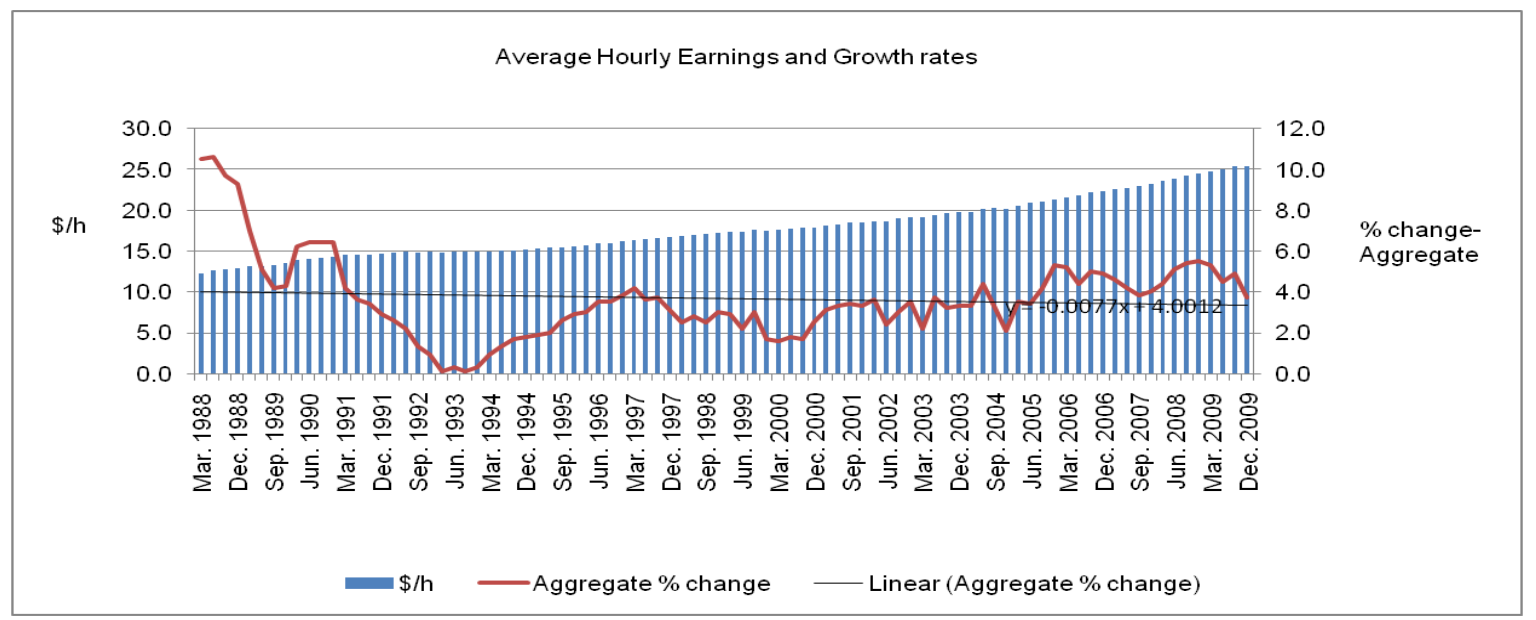

Figure 7 Average Hourly Earnings

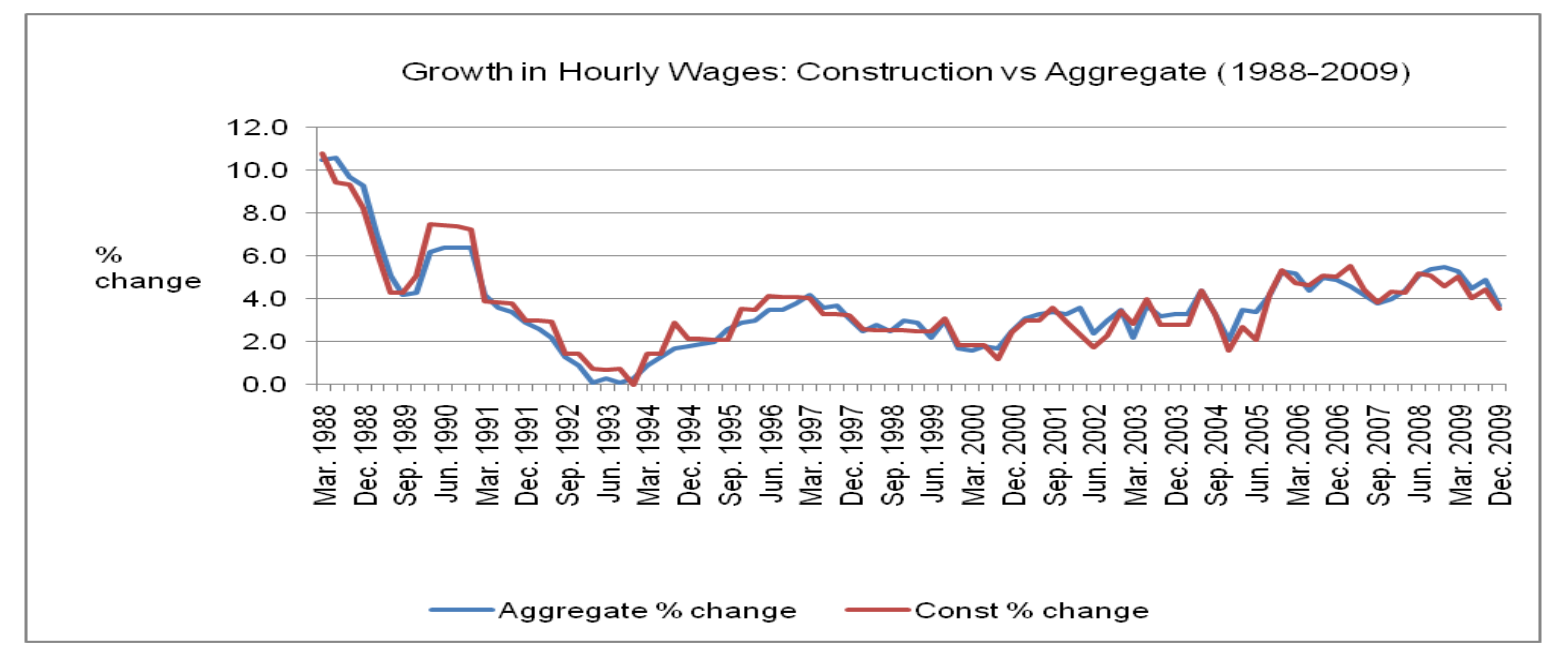

Figure 8 Growth in Hourly Wages: Construction v Aggregate (1988-2009)

Source: SNZ, RBNZ, DOL

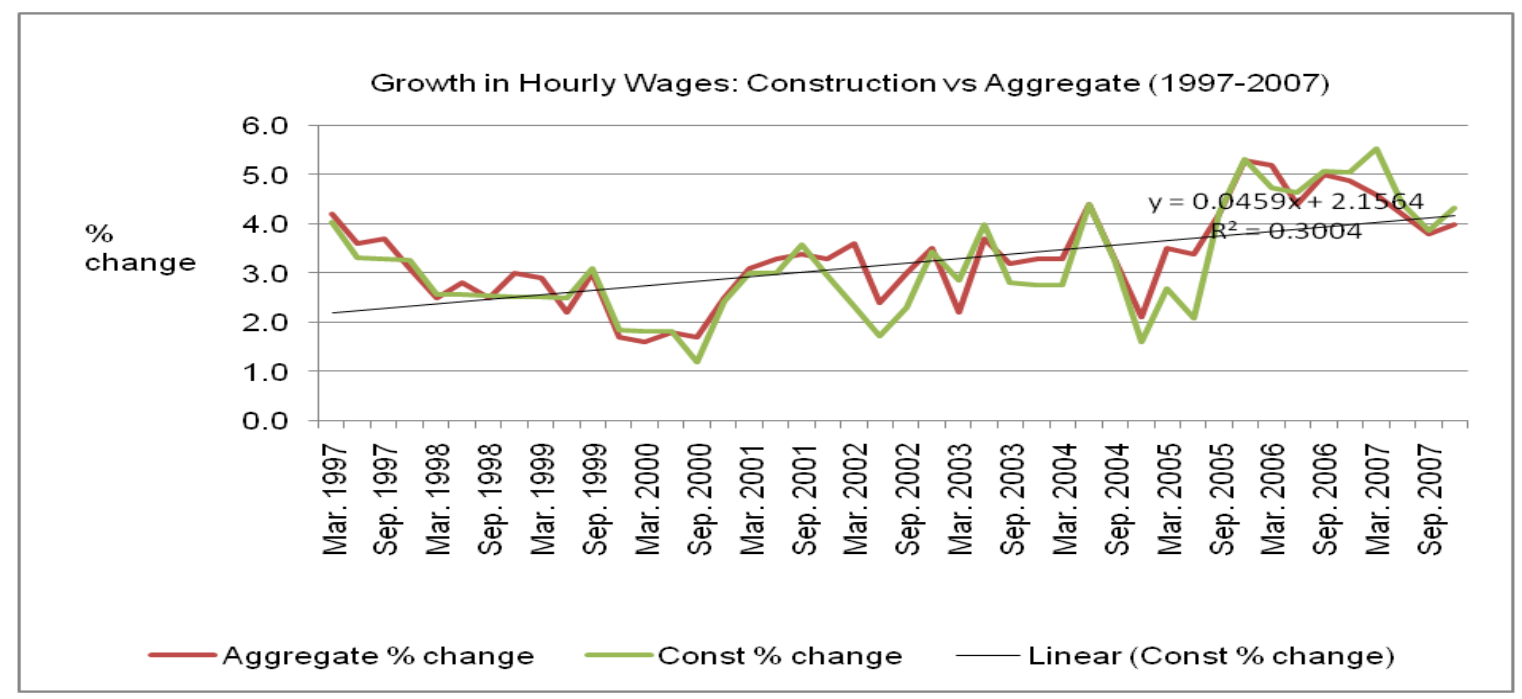

Figure 9 Growth in Hourly Wages: Construction v Aggregate (1997-2007)

Source: SNZ, RBNZ, DOL 


\section{Material Costs in Residential/Non-Residential Construction}

The materials index series was developed by BRANZ using collections of data obtained from SNZ, including materials prices for their Consumer Price and Producer Price Indexes (PPI). All materials have been re-based to 1000 in 1994. The time profiles of these indices are presented, along with their corresponding year over year growth rates (Fig. 10 \& 11). Over the period considered, material costs increased significantly. However, the rate of growth of the series averaged 3\% per annum. This finding means that the materials used in NZ residential construction tend to grow at a uniform rate in line with the more general inflation rate in the country. The result of the analysis above is similar to findings in the analysis of the labour costs series and it has implications on the analysis of labour productivity of NZ construction.

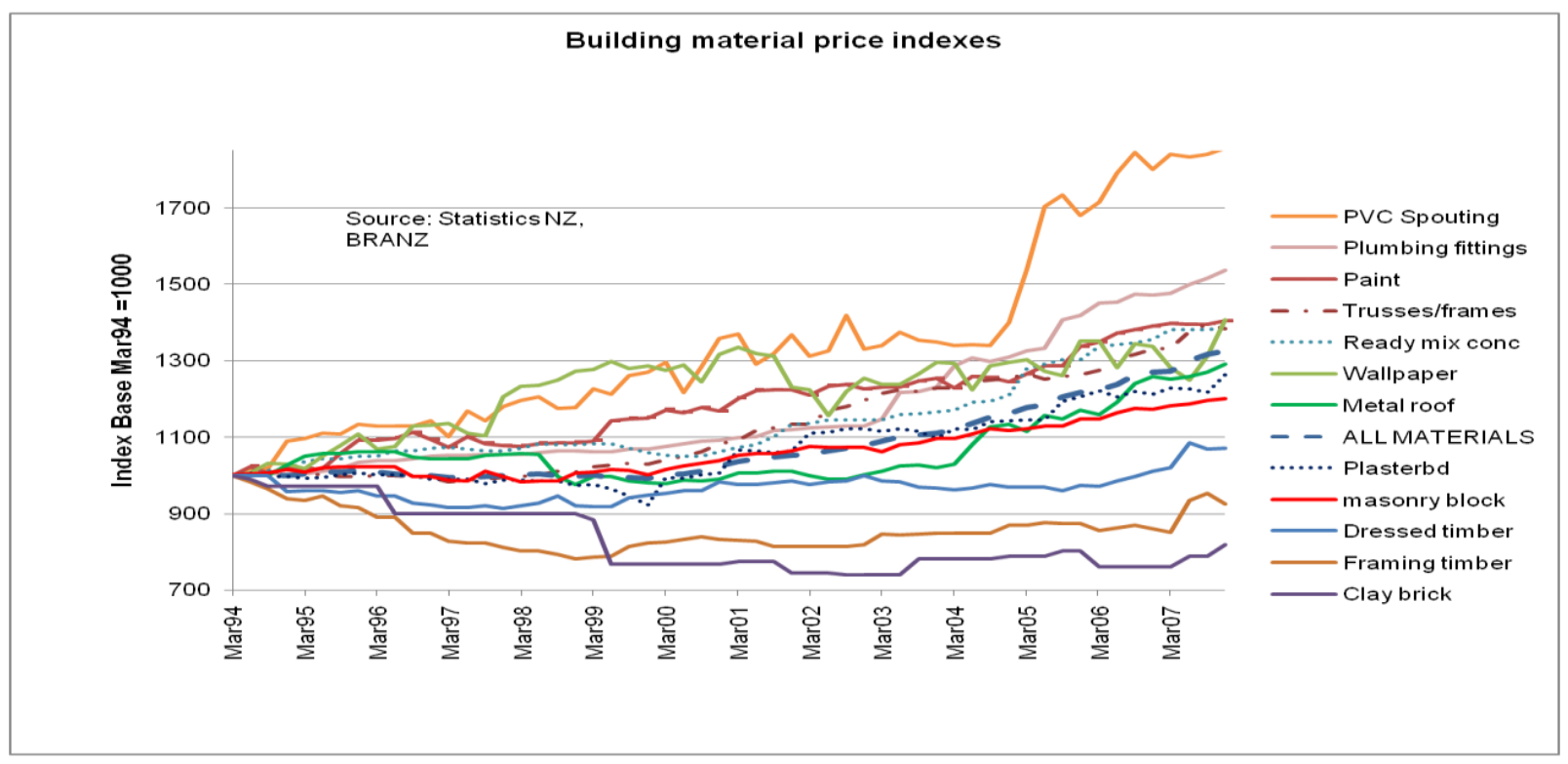

Figure 10 Material Price Index (All Materials)

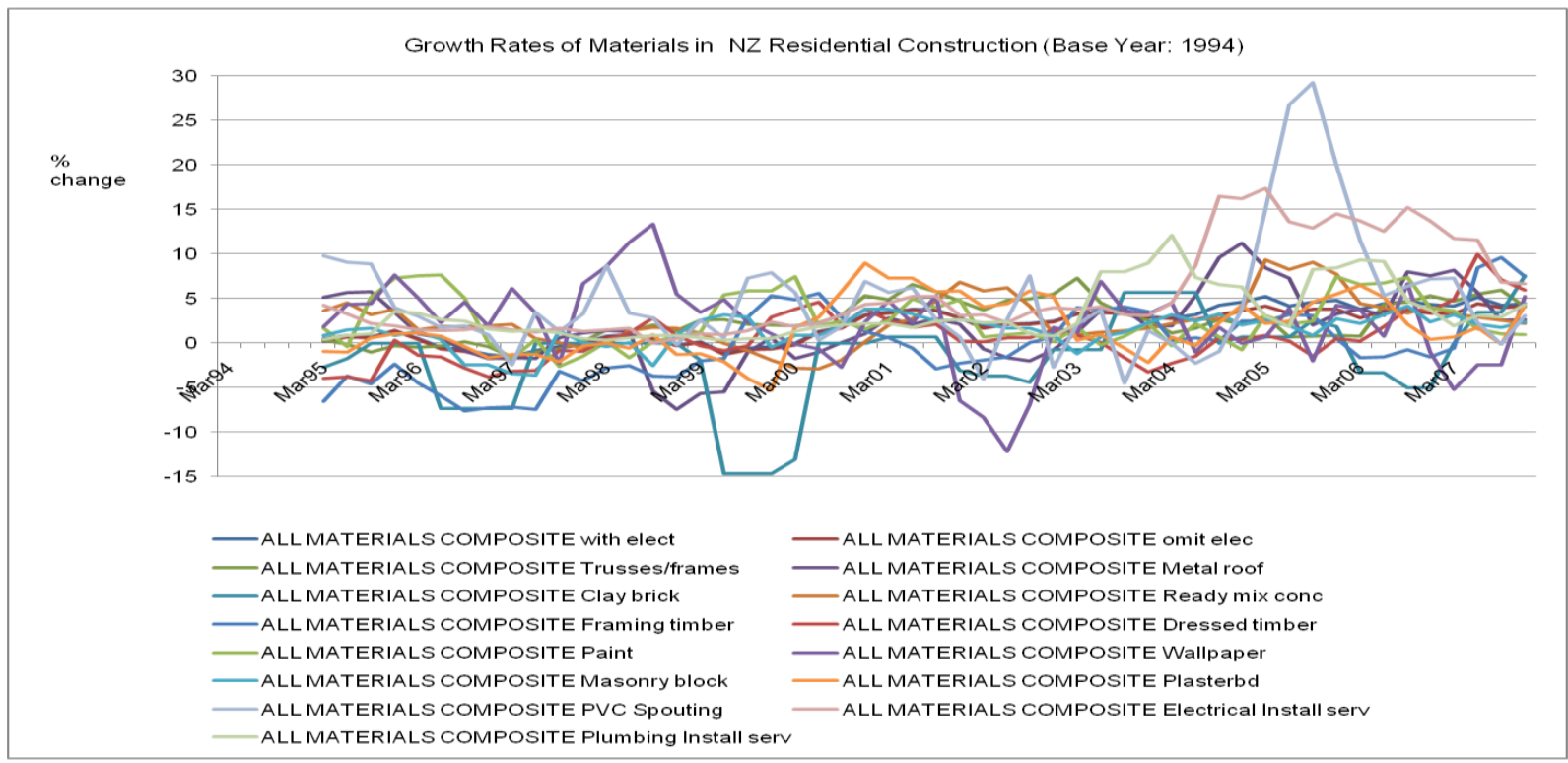

Figure 11 Growth Rates of Material Price Index (All Materials)

Source: SNZ, BRANZ

Tran, V and Tookey, J (2011) 'Labour productivity in the New Zealand construction industry: A thorough investigation', Australasian Journal of Construction Economics and Building, 11 (1) 41-60 


\section{Demand Side of NZ construction}

It is essential to explore the supply side as well as the demand side in NZ construction in order to obtain a full understanding of the nature of this industry. The supply side was discussed earlier (Employment, Labour and Material costs). In this section as well as the following three sections, the discussion of the demand side will be offered.

\section{Residential Construction: House and Land Prices}

Unlike previous investigations of labour productivity in NZ construction, we look into an important driver of the demand of construction work, i.e. the housing market, and any changes happening in this sub-sector between 1997 and 2007. The purpose of this inclusion is to identify whether the growth in this market had any effects on labour productivity and if they did, to what extent they influence the performance of productivity of the whole industry. Another reason for this consideration is that the house prices collectively include all associated costs (labour and material costs). This means in effect the housing market should be a real reflection of all factors discussed earlier.

House price data in this research is obtained from RBNZ. From 1990-2010, the value of NZ housing stock increased from NZ\$123 billion to NZ\$591 billion (Fig. 12). These figures show housing is a highly inflated market in NZ, with the annual inflation rate averaged at $7.5 \%$, in comparison to the rate of $3 \%$ in the wider economy over the same period. According to a number of studies by Motu Economic \& Public Policy Research, the increases in NZ house prices were mainly driven by the increase in land prices across NZ. These studies found that land prices in NZ increased significantly in the period from 1981-2004, with the real (inflation adjusted) price of vacant residential sections rising by $286 \%$ on average across the country (Grimes et al, 2006). These increases are most significant in metropolitan areas such as Auckland City (700\%), Manukau, North Shore City (both $460 \%$ ) or tourist areas such as Queenstown-Lakes and Thames-Corromandel (over 400\% each). These studies found that on average across the country, a $1 \%$ increase in real residential land prices translates into an estimated $0.27 \%$ increase in real house prices. Statistically, the effect is highly significant. In the absence of real land price increases, Grimes et al (2006) predicted that real house prices would have increased by just $16.4 \%$ (or $0.7 \%$ p.a.) over the 23 year period.

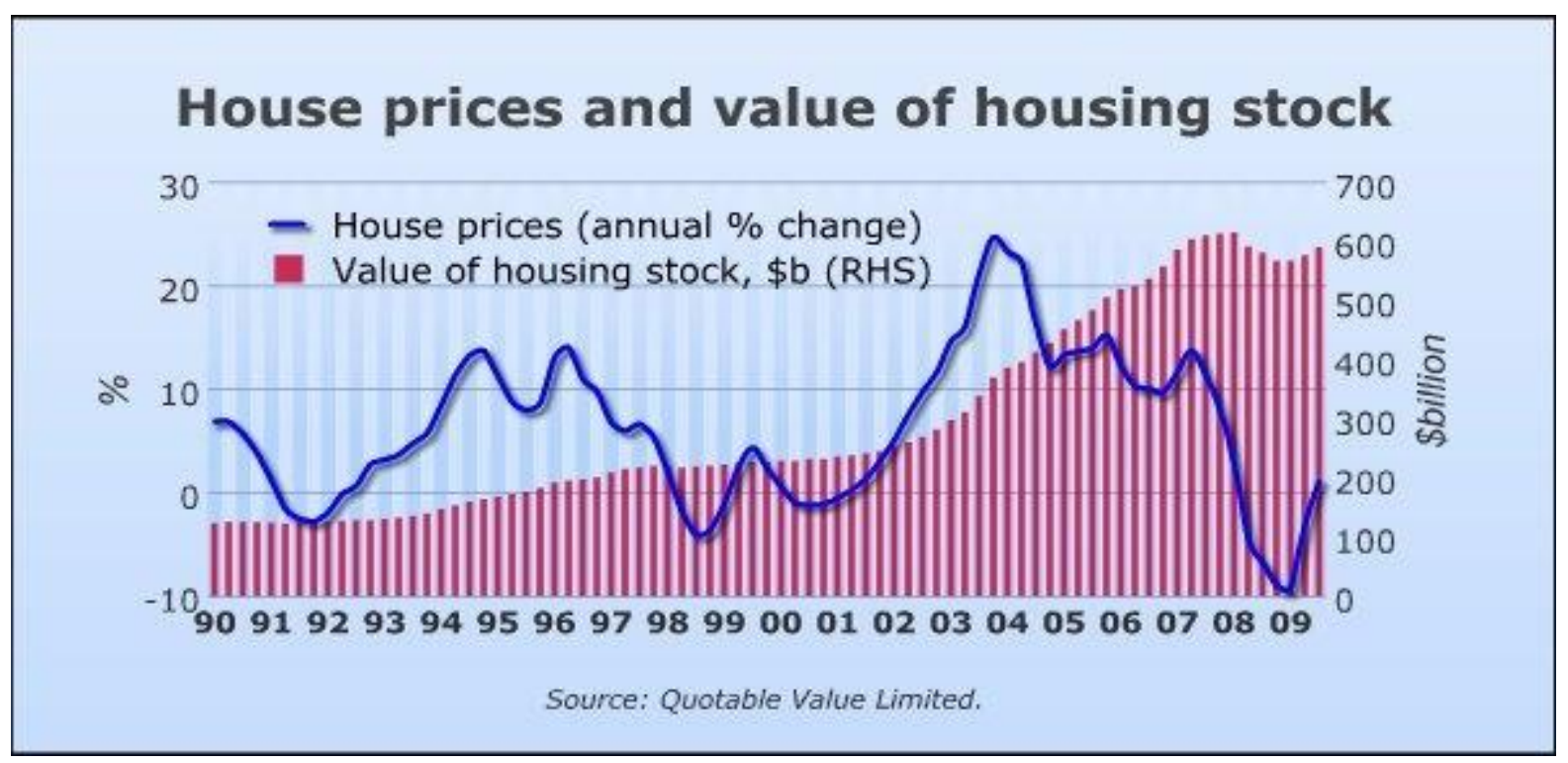

Figure 12 House Prices and Value of Housing Stock

Source: QV, RBNZ

Tran, V and Tookey, J (2011) 'Labour productivity in the New Zealand construction industry: A thorough investigation', Australasian Journal of Construction Economics and Building, 11 (1) 41-60 
On average, inflation of Residential Land Price in the period between 1985 and 2009 is 6.5\% p.a. Combined with results found in Motu's studies, land prices might have played a major role in the increase of house prices in NZ as observed. Note that rates of increases of both house and land prices are much higher than the inflation rate of the whole economy over the same period. This is highly significant. Property and built product prices are increasing $(6.5 \%$ pa) at a little over twice the rate that material and labour costs are (an NZ economy average of $3 \% \mathrm{pa}$ ). Thus rationally it could be expected that construction labour productivity should increase more rapidly than any of its comparable other industries. However, this is not the case. The skewing effect highlighted actually creates an artificially positive result in comparison to other industries. This is highly significant for the industry and needs further understanding in order to be rectified.

\section{Non-Residential Construction}

Data for non-residential construction in NZ are sourced from SNZ. These series date as far back as 1999 only. However, they should be sufficient in illustrating the performance of this sub-industry over the period considered in this research. As can be seen from Figures 1315, the Non-Residential sector has enjoyed a strong growth over the 10-year period to 2009. However, since the second half of 2006, demand for this sector seems to have decreased from the strong growth in previous years. Number of Building Consents in this period grew at slower pace and Value of Work Put in Place was flat. Demand for Commercial construction was greatest between 1999 and 2009. Given the prosperous period that the NZ economy had from 1999-2007, this comes with no surprise. However, with the recession in 2008 and the current economic climate, this demand has dwindled. The recession squeezed firms' profits and has left them with low reserves for investing in new buildings. Moreover, demand for new commercial buildings tends to lag economic growth. Therefore, the non-residential building sector was later to enter a downturn than the residential building sector and will also be later to see an upturn, as there are large areas of vacant office and retail space available. As for non-residential construction in other sectors, work on hospitals and nursing homes recorded the sharpest drop, down $39 \%$ in 2009. Work on hotels and boarding houses declined $7 \%$, factories and industrial buildings 5\% and miscellaneous buildings $11.6 \%$. The only exception to this trend was of the education buildings, in which the growth of $21 \%$ in 2009 was observed. The overall result is that value of non-residential building "Work Put in Place" fell $9.0 \%$ in the last quarter of 2009 . According to the RLB study, in the short run, the sector faces regulatory uncertainty over the government's tax reforms ( $R L B, 2010)$. The outlook for the non-residential sector is grim with the total value of non-residential building investment is expected to fall a further $17 \%$ over the next 12 months, before solid growth of $16 \%$ and $12 \%$ over the following two years (RLB, 2010).

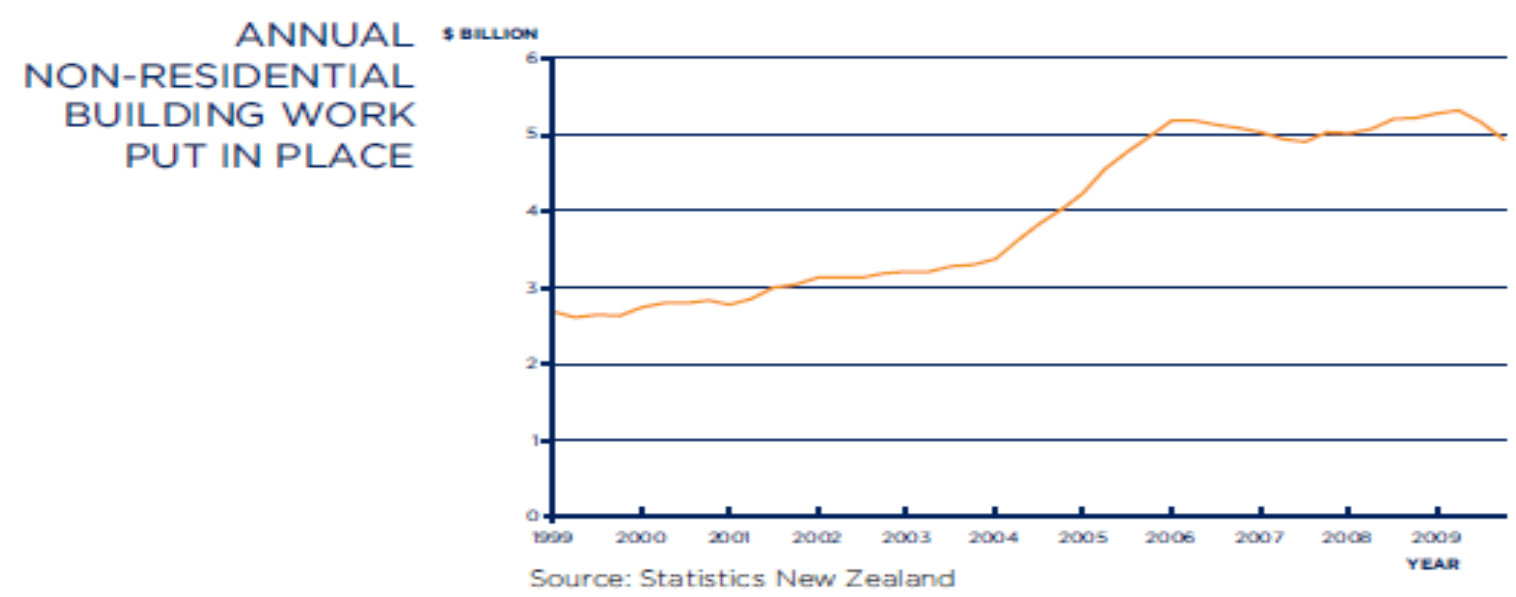

Figure 13 Annual Non-Residential Building Work Put in Place

Tran, V and Tookey, J (2011) 'Labour productivity in the New Zealand construction industry: A thorough investigation', Australasian Journal of Construction Economics and Building, 11 (1) 41-60 


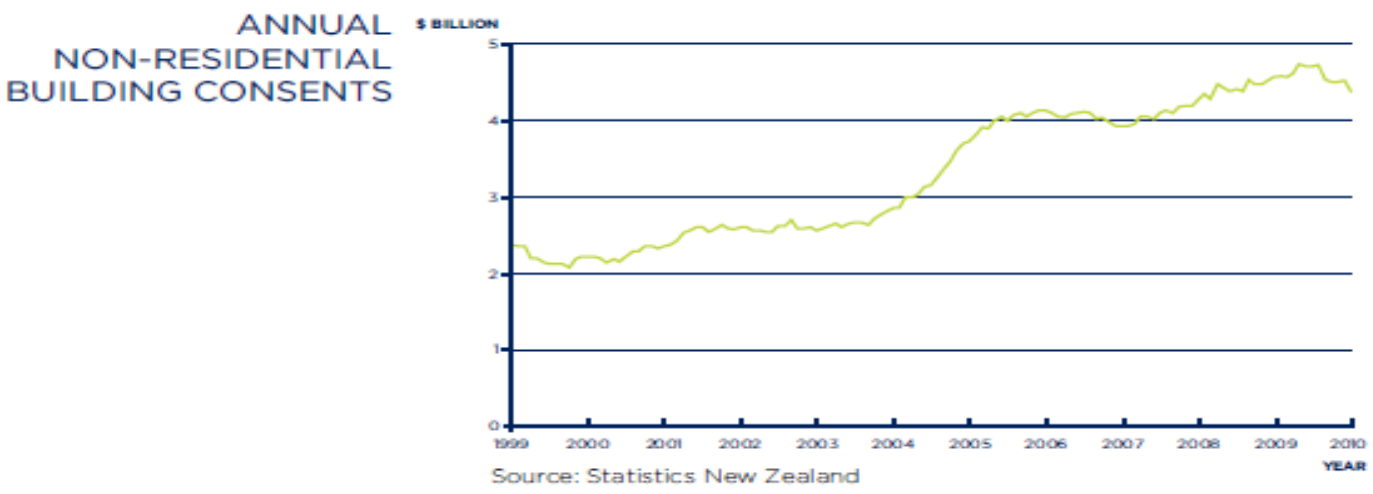

Figure14 Annual Non-Residential Building Consents

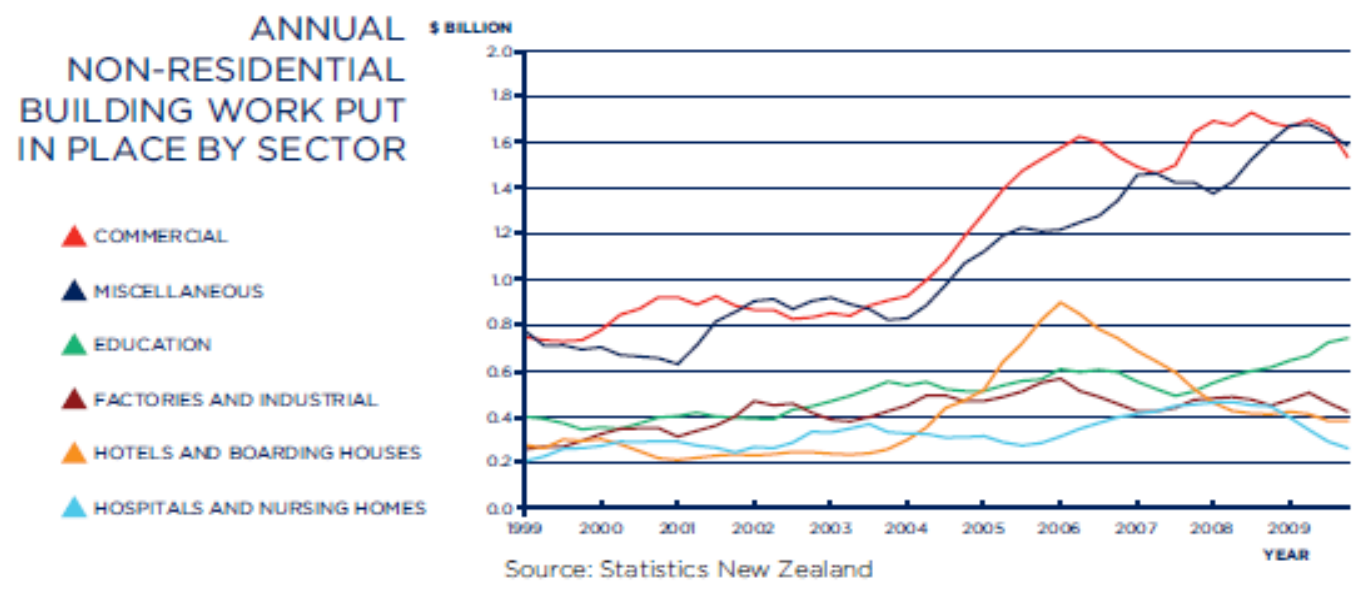

Figure 15: Annual Non-Residential Building Work Put in Place by Sector

ANNUAL TOTAL FLOOR

AREA AND AVERAGE

VALUE OF CONSENTS

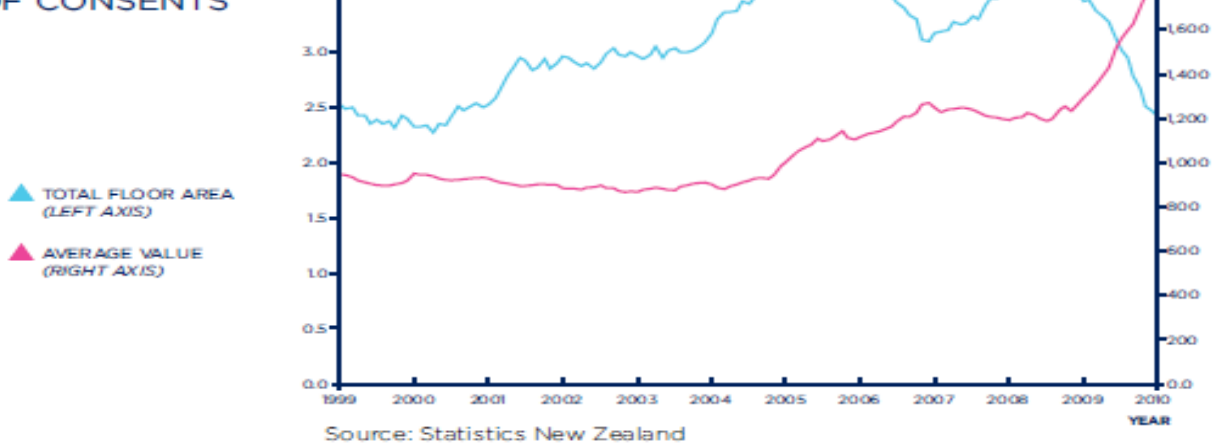

Figure 136: Annual Total Floor Area and Average Value of Consents

In the period considered (1997-2007), performance of the non-residential construction sector was generally good. Value of work in the sector was consistently increasing (see Figures 13 - 16). This trend was a reflection of the economic prosperity in NZ in this period. But, as construction labour productivity performance in this time was in general lower than that in other sectors; one may speculate that the rapid expansion of the labour pool of the industry and the quality of these trade personnel as well as training provided to them might have

Tran, V and Tookey, J (2011) 'Labour productivity in the New Zealand construction industry: A thorough investigation', Australasian Journal of Construction Economics and Building, 11 (1) 41-60 
been a major factor. However, at this instance, there is no data or study available to verify this speculation. A more rigorous investigation into this may be necessary.

\section{Infrastructure Construction}

At present it is not possible to get a measure of building productivity versus infrastructure construction productivity. All construction activity is quoted in a consolidated industry output figure. However, as has been previously noted, labour productivity from the civil sector is likely to be significantly higher than for the building sector. This is due to the different degrees of mechanisation inherent in each sector. However, this "probability" needs to be confirmed through research and/or through improved reporting.

\section{Construction GDP and Underlying Economic Trends}

Discussions in previous sections established that the three main sub-industries in NZ construction indeed make significant contributions to GDP. However, as Allan et al (2008) found, these sub-industries together with the construction industry on the whole are subjected to the economic conditions they operate within. Consequently, NZ construction seems to behave in accordance with the country's economic "cycles". The cyclical nature of the construction industry and its relationship with the economy are best represented by Figures 17 and 18. These figures summarise the results of a study into a 20-year cycle in the NZ construction sector (RCP, 2005). A number of economic features (share market performances, currency and commodity prices, and import-export trends) were included and summarised here to illustrate their effects on all factors discussed above (interest, house prices and associated costs, investments in the sector). Overall, the RCP study demonstrated consistency with the CAENZ study.

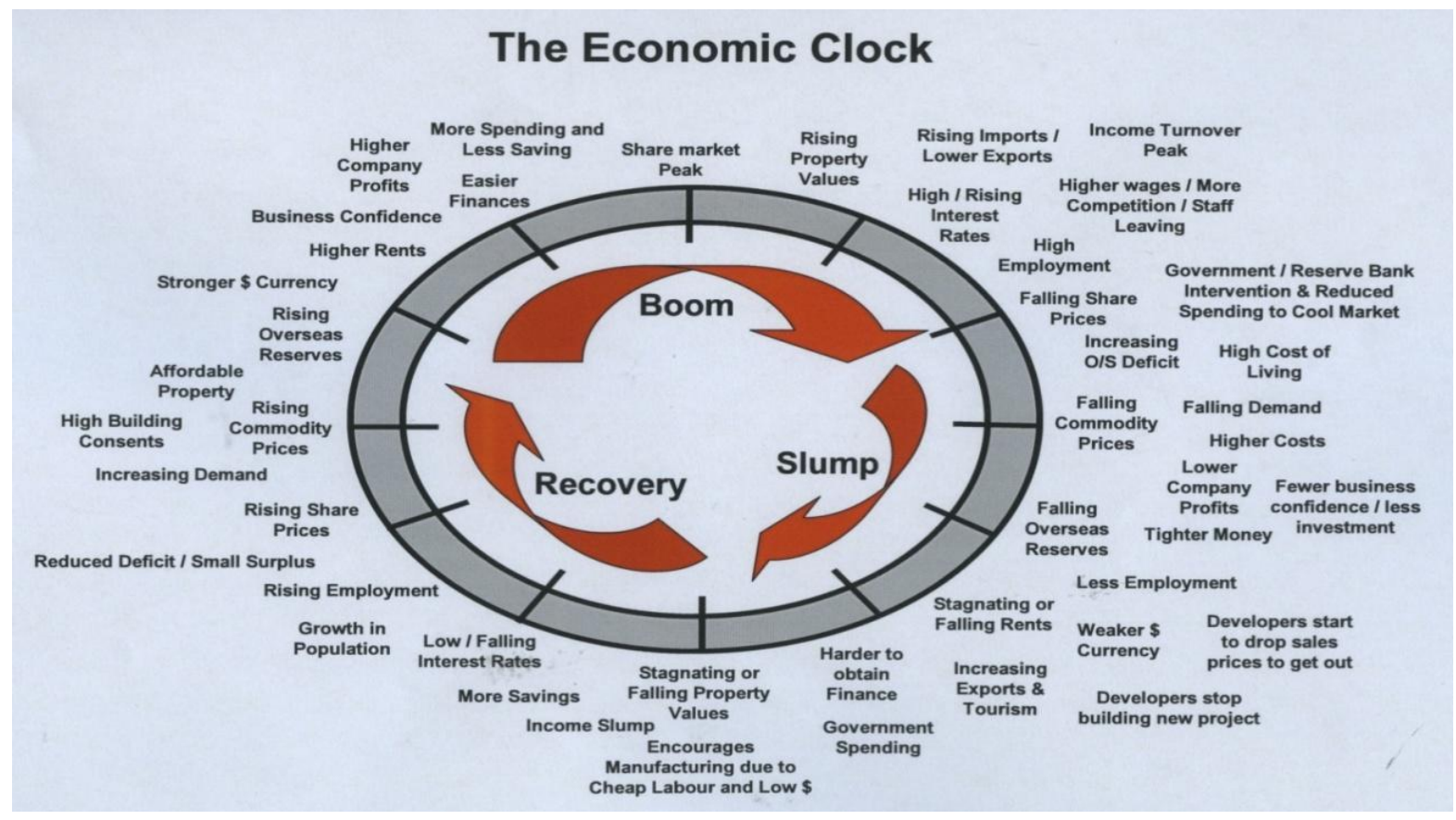

Figure 17 The Economic Clock

Source: RCP

Tran, V and Tookey, J (2011) 'Labour productivity in the New Zealand construction industry: A thorough investigation', Australasian Journal of Construction Economics and Building, 11 (1) 41-60 


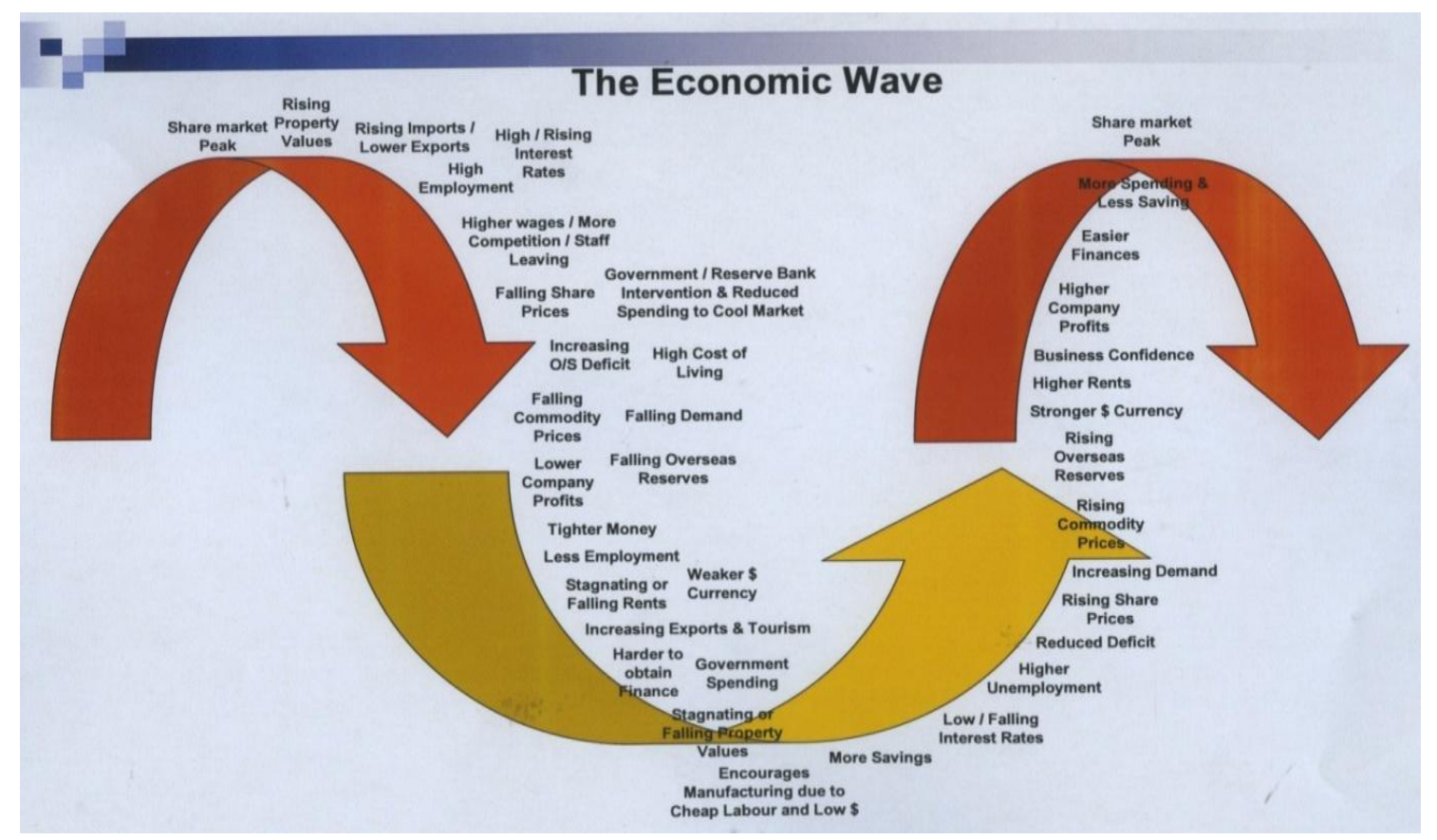

Figure 148 The Economic Waves

Source: RCP

Analyses of these sub-industries have shown that this industry have higher output value than many other sectors in NZ economy between 1997 and 2007. This finding should have positive impact on productivity of NZ construction given the positive relationship between output and labour productivity as established in section 2 . There may be other factors that influence this performance and more research need to be carried out.

\section{Discussion of Research Results}

\section{Factors Affecting Performance of NZ construction Labour Productivity}

A number of factors such as the national inflation rates, construction employment and construction costs were explored and discussed in detail. In addition, three main subindustries in NZ construction were also included in the investigation. These sectors, and their associated extraneous variables, provided some useful information in relation to the "real" performance of NZ construction labour productivity. This is in contrast to previous productivity studies in NZ, where observed performances were presented by facts and statistical figures without having their causes properly identified.

Results from analysis show that since the early 1990's, while factors influencing outputs (house and land prices) have increased significantly, factors impacting inputs (labour and material costs) have remained relatively stable. Given the relationships between outputs and labour productivity established in section 2 and the statistical results from section 6 , one would expect labour productivity in the NZ construction sector to perform exceptionally well in comparison with other industries. However, despite this logical belief, labour productivity in this industry has remained flat throughout and actually declined during the construction boom (2003-2007). Moreover, factors that affect value of construction outputs most significantly are land and house prices, because the period considered (1997-2007) was mainly driven by demand for construction work in the residential area. Previous productivity studies in NZ seemed to have ignored the effects of these increases in their calculations. Despite this omission, their conclusions have been consistent, i.e. productivity in NZ construction has been poor. Therefore, when these factors, together with value of output of non-residential construction are taken into consideration, labour productivity performance of construction might actually have been much worse than that reported in previous studies. However, more research is required in the future in order to verify these hypotheses.

Tran, V and Tookey, J (2011) 'Labour productivity in the New Zealand construction industry: A thorough investigation', Australasian Journal of Construction Economics and Building, 11 (1) 41-60 
Based on statistical tests, a set of mathematical relationships between labour productivity and related factors was established as follows:

$$
\begin{aligned}
& L \sim P_{\mathrm{h}} \\
& L \sim P_{\mathrm{l}} \\
& L \sim G D P_{\text {const }} \\
& L \sim E_{\text {const }}
\end{aligned}
$$

$$
\begin{aligned}
& G D P_{\text {const }} \sim \frac{1}{B C l} \\
& P_{h} \sim C_{\text {labour }} \\
& P_{h} \sim C_{\text {material }}
\end{aligned}
$$

where L:Labour Productivity: $P_{h}:$ House Price; $P_{l}:$ Land Price; GDP $P_{\text {const }}:$ Construction GDP $E_{\text {const: }}$ : Construction Employment; $B C l: B$ uilding Consent lssued; $C_{\text {labour: Labour Cost }}$ and $C_{\text {material }}$ Material Cost.

One key issue that was repeatedly emphasised in the literature is the seasonality of the skill base and the adequacy of skill levels of personnel in the construction industry. The pool of experienced and skilled personnel changes drastically in accordance with underlying economic conditions, i.e. during the boom period, employment in construction tends to grow exceptionally high (mainly in the unskilled occupation categories) while during slow periods, the reverse is true (Allan et al, 2008; DOL, 2009). This fluctuation in labour availability makes it hard for firms in the NZ construction industry to operate efficiently as they tend to experience skill shortages during prosperous periods but difficulties to hold on to their experienced staff in hard times due to the availability of work and to each firm's financial health. The direct consequence of this is on the performance of labour productivity, where it tends to exhibit a choppy behaviour as observed. It can be argued that a well-equipped skilled workforce may be a backbone for any future growth in labour productivity if the industry decides to take actions to mitigate this chronic problem. Hence, research is required into the relationship between skills and productivity in NZ construction.

\section{Limitation of Research}

Results from this research are constrained by the available data. This section offers some discussions on a number of limitations in this research. The most notable restriction on this research is the scope. A number of other influences could have been explored but were omitted such as the effects of innovation in the construction industry. Other areas include investigations of sub-industries other than those considered (civil works, demolition and Building Services for example) which should be considered for a full investigation on productivity of the industry.

\section{Research Summary}

This research has endeavoured to contribute to the development of an understanding of labour productivity in the NZ construction industry. It is undeniable that NZ construction plays an important role both directly and indirectly in the nation's economic growth, but the industry's "productiveness" has decreased over time and this may have significant adverse effects on the nation's "quality of life". A number of studies have attempted to investigate these issues. However, review of recent literature revealed that labour productivity is not well understood in the construction industry. Further, these studies seemed to have relied on published statistics to construct their productivity series without trying to fully incorporate the underlying dynamics of NZ construction. As a result, their findings may be biased and recommendations tend to be limited in scope.

The current research revealed that extraneous factors such as land and material costs have significant influences on labour productivity of NZ construction. Between 1997 and 2007, the basic construction costs (material and labour) remained stable while values of works grew at significantly higher rates. This result suggests that, in theory, NZ construction should have performed exceptionally well in terms of labour productivity. However, productivity statistics showed that overall the performance of NZ construction was actually decreasing. This contradiction suggests that when extraneous factors are taken into consideration, labour

Tran, V and Tookey, J (2011) 'Labour productivity in the New Zealand construction industry: A thorough investigation', Australasian Journal of Construction Economics and Building, 11 (1) 41-60 
productivity might have performed much worse than we had expected. Investigations need to test this hypothesis and to build a concrete foundation for further work in this area.

\section{References}

Allan. N, Yin. Y, Scheepbouwer. E (2008) 'A study into the Cyclical Performance of the New Zealand Construction Industry', New Zealand Centre for Advanced Engineering, Christchurch, New Zealand

APMF Study Guide (2010) 'Quantitative Research Techniques', Marketing Research

Barr. P.S (2004) 'Research Methodology in Strategy and Management, Volume 1', Elsevier Ltd, Emerald Group Publishing Limited

Black. M, Guy. M, McLellan. N (2003) 'Productivity in New Zealand 1998 to 2002', New Zealand Treasury, Wellington 6008, New Zealand

Burney. A. (2008) 'Inductive and Deductive Research Approach', Department of Computer Science, University of Karachi

Christou. E. Et al (2007) 'Research Methodology in Hospitality Industry: The role of the Inquiry Paradigms', University of The Aegean, Mihalon 8, 82100, Chios, Greece

Country Health Information Profiles (2010) 'New Zealand', World Health Organisation, http://www.wpro.who.int/countries/2009/nez/

Cumming. G (2002) 'Caught in a ripple effect from Sep 11', The New Zealand Herald, NZ

Davis. N (2007), 'Construction Sector Productivity-Scoping Report', Martin-Jenkins, Wellington, New Zealand

De Vaus, D (2005) 'Research design in Social Research', New York University, New York, USA

Del Siegle (2010) 'Qualitative Research Design', University of Connecticut, Connecticut, USA

Department of Housing and Building (2009), 'Report of the Building and Construction Sector Productivity Taskforce-A modern efficiency and productive New Zealand built infrastructure industry', Department of Housing and Building, Wellington, New Zealand

Department of Labour (2008) 'Construction Sector Outlook', Department of Labour, New Zealand Government, Wellington

Department of Labour (2009) 'Skills in the Labour Market Outlook', Department of Labour, New Zealand Government, Wellington

Department of Labour (2009) 'Labour Market Outlook', Department of Labour, New Zealand Government, Wellington

Department of Labour (2005) 'Construction Industry-Workforce Trends', Department of Labour, New Zealand Government, Wellington

Drew. A (2007) 'New Zealand's productivity performance and prospect', Reserve Bank of New Zealand, Wellington, New Zealand

Fallow. B (2008) 'Omen of recession seen in economy', The New Zealand Herald, NZ

Grimes. A \& Aitken. A (2006) 'Regional Housing Markets in New Zealand: House Price, Sales and Supply Responses', Motu Economic and Public Policy Research, Wellington, NZ

Gruber. T. (1993) 'A Translation Approach to Portable Ontology Specifications', Knowledge Systems Laboratory, Computer Science Department, Stanford University, CA

Holzer. M, Nagel. S.S. (1985) 'Productivity and Public Policy', Sage Publications, Beverly Hills, California, USA

Tran, V and Tookey, J (2011) 'Labour productivity in the New Zealand construction industry: A thorough investigation', Australasian Journal of Construction Economics and Building, 11 (1) 41-60 
Hopkins. W. G. (2000) 'Quantitative Research Design', Department of Physiology, University of Otago, Dunedin 9001, New Zealand

Infometrics (2008) 'Employment profile and future demand for Crane Operators in New Zealand', Infometrics Ltd, New Zealand

Janssen. J, McLoughlin. S (2008) 'New Zealand's Productivity Performance', New Zealand Treasury, Wellington 6015, New Zealand

Mare. D, Hyslop. D (2008) 'Cyclical Earnings Variation and the Composition of Employment', Statistics New Zealand, Wellington, New Zealand

Merry. A, Spearpoint. M (2008) 'The Building Act 2004 and the New Zealand Fire Service', New Zealand Fire Service, Christchurch, New Zealand

Ministry of Agriculture and Forestry (2001) 'New Zealand Statistics', MAF, Wellington, New Zealand, link: http://www.maf.govt.nz/statistics/forestry/annual/nzstats2000/index.htm

New Zealand Treasury (2010) 'Overview of New Zealand economy', New Zealand Treasury, Wellington, New Zealand, link: http://www.treasury.govt.nz/economy/overview

NZPA (2002) 'Economic stability has labour market buzzing', The New Zealand Herald, NZ

Oram. R (1999) 'House prices take 7pc hit', The New Zealand Herald, New Zealand

Organisation for Economic Co-operation and Development (2002) 'Measuring ProductivityOECD Manual', OECD

Organisation for Economic Co-operation and Development (2007) 'Economic Survey of New Zealand', OECD

Rajasekar. S. et al (2006) 'Research Methodology', School of Physics, Bharathidasan University, Tiruchirapalli 620024, Tamilnadu, India

Rankin. K (1995) 'New Zealand 1995: a Miracle Economy?', Department of Economics, the University of Auckland, Auckland, New Zealand

Rawnsley. M (1998) 'Ontology, Epistemology, and Methodology: A Clarification', Nursing Science Quarterly, Sage Publications

Rider, Levett, Bucknall (March 2010) 'New Zealand Trends in Property and Construction', New Zealand

Saravanaperumal. M (2008) 'Labour Market Adjustment in the Construction Industry 20012006', Statistics New Zealand, Wellington, New Zealand

Selkirk. D (2010) 'The Building Act 2004: Major Implications for Property Developers, Builders and Vendors', Fortune Manning Lawyers, Auckland, New Zealand

Statistics New Zealand (2009) 'A Statistical Overview of the Construction Industry from 2000 to 2008', Statistics New Zealand, Christchurch, New Zealand

Trochim. W.M.K. (2006) 'Research Methods Knowledge Base', Atomic Dog Publication, Cincinnati, Ohio, USA

University of Alabama in Huntsville (2010) 'Types of Research Designs', University of Alabama in Huntsville, USA 